\title{
Pengaruh Profitabilitas, Komite Audit dan Kepemilikan Asing Terhadap Kebijakan Dividen (Studi pada Perusahaan Properti, Real Estate dan Konstruksi Bangunan yang Terdaftar di Bursa Efek Indonesia Tahun 2014-2018)
}

\author{
(The Effect of Profitability, Audit Committee and Foreign Ownership on Dividend Policy \\ (Study on Property, Real Estate and Construction Building Companies Listed in Bursa \\ Efek Indonesia Years 2014-2018)
}

\author{
Awiah Fitriyani* \\ Jurusan Akuntansi, Fakultas Ekonomi dan Bisnis, Universitas Muhammadiyah Prof. Dr. Hamka \\ Jln. Raya Bogor Km.23 No.99, Kec. Ciracas, Kota Jakarta Timur 13830 \\ E-mail: awiahfitriyani97@gmail.com
}

\begin{abstract}
Abstrak
Penelitian ini bertujuan untuk mengetahui pengaruh profitabilitas yang diukur dengan return on equity, komite audit dan kepemilikan asing terhadap kebijakan dividen yang diukur dengan dividen payout ratio.Pengambilan sampel dilakukan dengan teknik purposive sampling. Sehingga sampel yang digunakan dalam penelitian sebanyak 45 sampel terdiri dar 9 perusahaan properti, real estate, konstruksi dan bangunan yang terdaftar di Bursa Efek Indonesia dengan periode penelitian dari tahun 2014 - 2018. Hasil penelitian ini menunjukkan bahwa secara parsial Return on Equity berpengaruh signikan terhadap Dividend Payout Ratio, Komite Audit tidak berpengaruh signifikan terhadap Dividend Payout Ratio dan Kepemilikan Asing berpengaruh signifikan terhadap Dividend Payout Ratio. Selain itu, hasil penelitian secara simultan bahwa Return on Equity, Komite Audit dan Kepemilikan Asing terhadap Dividen Payout Ratio berpengaruh signifikan terhadap Dividen Payout Ratio.
\end{abstract}

Kata Kunci: Return on Equity, Komite Audit, Kepemilikan Asing dan Dividend Payout Ratio.

\begin{abstract}
This study aims to determine the effect of profitability as measured by return on equity, audit committee and foreign ownership on dividend policy as measured by dividend payout ratio. So sample used in research this as many as 45 samples, consistingfom 9 companies registered in the property, real estate, construction and building companies listed on the Indonesia Stock Excange with period years 2014-2018. The results of this study indicate that partially Return on Equity significantly influences the Dividend Payout Ratio, the Audit Committee does not significantly influence the Dividend Payout Ratio and Foreign Ownership has a significant effect on the Dividend Payout Ratio. In addition, the results of the simultaneous study that Return on Equity, Audit Committee and Foreign Ownership of Dividend Payout Ratio have a significant effect on Dividend Payout Ratio.
\end{abstract}

Keywords: Return On Equity, Audit Committee, Foreign Ownership, Dividend Policy.

\section{Pendahuluan}

Perkembangan ekonomi dalam negara dapat dilihat dengan sudut pandang yang berbeda, salah satunya dengan mengetahui tingkat perkembangan aktivitas pasar modal. Dalam aktivitas pasar modal, investor akan mengharapkan pengembalian dari investasi yang dilakukannya berupa dividen Linawati \& Amilin (2015). Umumnya setiap perusahaan dalam membagikan dividen perlu mempertimbangkan sebagian laba guna diinvestasikan kembali sebagai peluang usaha yang lebih menguntungkan.

Di Indonesia keputusan pembagian dividen ditentukan dalam Rapat Umum Pemegang Saham (RUPS). Kebijakan dividen diputuskan dari negosiasi yang terbentuk oleh pihak manajemen dan pemegang sahamnya. Sehingga sangat perlu dipertimbangkan mengenai faktor-faktor yang dianggap penting mempengaruhi kebijakan dividen di perusahaan tersebut. Dividen merupakan keuntungan yang dibagikan oleh perusahaan kepada investor. Kebijakan dividen merupakan kebijakan yang dibuat oleh perusahaan dalam menetapkan proposi pendapatan yang dibagikan sebagai dividend proposi laba yang ditahan perusahaan untuk diinvestasikan kembali. Kebijakan dividen menurut Sudana (2011:167) berhubungan dengan besarnya dividend payout ratio. Semakin tinggi dividend payout ratio yang ditetapkan perusahaan maka semakin kecil pula dana yang akan ditanamkan kembali didalam perusahaan yang berarti akan menghambat pertumbuhan perusahaan dan Jumlah alokasi laba yang dapat ditahan perusahaan dan laba yang dapat dibagikan kepada para pemegang saham telah ditentukan dalam kebijakan dividen. Bagi perusahaan, pilihan untuk membagikan laba dalam bentuk dividen akan mengurangi sumber dana internalnya.

Kepemilikan saham diperusahaan di Indonesia cenderung memiliki struktur kepemilikan saham yang terkonsentrasi. Kondisi ini menggambarkan penggendalian masih berkonsentarasi pada investor besar (pemegang saham mayoritas). Pemegang saham mayoritas memiliki pengaruh yang sangat besar terhadap penerapan kebijakan dividen dalam perusahaan.Pemegang saham mayoritas dapat menetapkan kebijakan yanag bertentangan dengan

\footnotetext{
* Corresponding author
} 
kepentingan pemegang saham minoritas. Hal ini disebut dengan agency problem dimana sahamnya terkonsentrasi.

Penerapan pelaksanaan good corporate governance yang diharapkan dapat meningkatkan kualitas laporan keuangan yang ada pada akhirnaya dapat meningkatkan daya informasi akuntansi. Good corporate governance merupakan cara untuk memberikan keyakinan kepada para pemasok dana perusahaan akan diperolehnya pengembalian (return) atas investasi mereka. Selain itu good corporate governance juga merupakan suatu system untuk mengarahkan dan mengendalikan suatu perusahaan atau korporasi (Setyaningrum, 2012).

Salah satu yang terdapat di good corporate governance itu adalah Komite Audit yang berfungsi untuk memastikan bahwa operasional sehari-hari berjalan sesuai kebijakan yang ditetapkan oleh perusahaan dan memastikan bahwa laporan keuangan yang disajikan sudah sesuai dengan standar akuntansi keuangan yang berterima umum di Indonesia. Dengan adanya komite audit diharapkan mampu meningkatkan pengawasan internal perusahaan dan mampu membuat pertimbangan yang ditujukan pada para pemegang saham. Dalam penilitian Komite Audit dengan kebijakan dividen. Kumalasari (2017) menyimpulkan bahwa tidak ada hubungan yang signifikan antara Komite Audit dengan kebijakan dividen. Sedangkan Septiani (2013) menyatakan bahwa Komite Audit memiliki pengaruh positif yang signifikan terhadap kebijakan dividen.

Berdasarkan Peraturan Menteri Keuangan No 153/PMK.010/2010 tentang kepemilikan saham dan permodalan perusahaan efek. Pemodal asing adalah orang perseoramgam warga negara asing atau badan hokum asing. Secara umum kepemilikan asing diartikan sebagai kepemilikan saham investor asing dari total mosal saham.

Menurut Chai (2010) kepemilikan asing memiliki pengaruh penting terhadap kebijakan dividen perusahaan. Lucyanda dan Lucyanda \& Lilyana (2012) menyatakan bahwa keberadaan investor asing dalam strukur kepemilikan perusahaan diharapkan akan menaikan kinerja perusahaan karena akan menambah tekanan kepada manajer dalam menyediakan tambahan pengawasan, dapat memberikan modal-modal baru dan memperkerjakan manajer yang sudah terlatih dan membantu perusahaan lokal miliknya untuk terdaftar di pasar internasional yang mengakibatkan biaya perolehan modalnya semakin berkurang.

Investor asing lebih menyukai perusahaan menanam labanya daripada membayarkannya sebagai dividen sehubungan dengan adanya pajak dividen yang tinggi, sehingga adanya kepemilikan asing dalam struktur kepemilikan perusahaan tidak mempengaruihi besar kecilnya pembayaran dividen yang dibayarkan. Di Indonesia terdapat undang-undang yang mengatur tentang pajak dividen yaitu Undang-Undang Republik Indonesia Nomor 17 Tahun 2000 tentang Pajak penghasilan, dimana dalam undang-undang tersebut menyebutkan bahwa wajib pajak yang dikenakan pajak dividen sebesar $15 \%$ untuk investor dalam negeri (pasal 23) dan 20\% untuk investor luar negeri (pasal 26).

Dengan adanya pajak atas dividen yang tinggi, terutama bagi investor luar negeri ini menyebabkan investor luar negeri cenderung lbih menyukai perusahaan menahan labanya dari pada membayarkannya sebagai dividen. Menurut Wahyudi
(2013) menyatakan bahwa kepemilikan asing tidak berpengaruh signifikan pada kebijakan dividen. Baik dalam hal mendorong manajemen untuk melakukan pembayaran dividen yang lebih besar maupun kecuali. Pengaruh kepemilikan asing terhadap kebijakan dividen yang tidak signifikan ini mendukung penelitian Lucyanda \& Lilyana (2012).

Berdasarkan pemaparan tersebut dan hasil penelitian sebelumnya, maka peneliti tertarik untuk melakukan penelitian tentang "Pengaruh Profitabilitas, Komite Audit dan Kepemilikan Asing Terhadap Kebijakan Dividen (Studi Pada Perusahaan Properti, Real Estate, Konstruksi dan Bangunan yang Terdaftar di Bursa Efek Indonesia Tahun 2014-108)”.

\section{Metode}

\section{Rancangan Penelitian}

penelitian ini, peneliti menggunakan metode penelitian ekplanasi. Metode eksplanasi adalah suatu metode penelitian yang menggambarkan dua variabel yang diteliti, yaitu variabel bebas dan variabel terikat yang kemudian menjelaskan hubungan atau pengaruh kedua variabel tersebut (Sugiyono, 2011).

\section{Jenis dan Sumber Data}

Jenis data yang digunakan dalam penelitian ini adalah data kuantitatif yang berupa laporan keuangan pada perusahaan properti, real estate, konstruksi dan bangunan yang terdapat di Bursa Efek Indonesia tahun 2014 - 2018. Sedangkan sumber data yang digunakan dalam penelitian ini adalah dengan mengakses website PT Bursa Efek Indonesia (www.idx.co.id) atau website Jakarta \& Indonesia Stock Exchange Indonesia Finance Market (www.idnfinancials.com).

\section{Populasi dan Sampel}

Popolusi adalah keseluruhan objek atau subjek yang berada pada suatu wilayah dan memenuhi syarat-syarat tertentu berkaitan dengan masalah Nanang (2014:76). Populasi ini terdiri atas perusahaan properti, real estate dan konstruksi bangunan yang terdaftar di Bursa Efek Indonesia berjumlah 9 perusahaan.

Sampel adalah anggota populasi yang dipilih dengan menggunakan metode tertentu sehingga diharapkan dapat mewakili populasi Nanang (2014:77). Pengambilan sampel menggunakan teknik purposive sampling dengan kriteria sampel sebagai berikut:

Tabel 1. Kriteria Pemilihan Sampel

\begin{tabular}{|c|c|c|}
\hline No. & Keterangan & Jumlah \\
\hline 1. & $\begin{array}{l}\text { Perusahaan properti, real estate dan } \\
\text { konstruksi bangunan }\end{array}$ & 77 \\
\hline 2. & Perusahaan properti, real estate dan & 56 \\
\hline
\end{tabular}

konstruksi bangunan yang menerbitkan laporan keuangan yang telah diaudit setiap tahun selama periode tahun 20142018

3. Perusahaan properti, real estate dan konstruksi bangunan yang menghasilkan laba pada tahun 2014-2018

4. Perusahaan properti, real estate dan 20 
konstruksi bangunan yang membagikan pada tahun 2014-2018 secara berturutturut

5. Perusahaan properti, real estate dan konstruksi bangunan yang memiliki kepemilikan asing pada tahun 20142018

Jumlah sampel 9x5 (lima) tahun penelitian 45

Sumber : diolah oleh peneliti, 2019

\section{Metode Analisis Data}

Metode analisis data yang digunakan adalah analisis deskriptif statistik, analisis regresi linier berganda, uji asumsi klasik dan uji hipotesis. Uji asumsi klasik meliputi uji normalitas, ujimultikolinieritas, uji heteroskedastisitas dan uji autokorelasi. Uji hipotesis yang digunakan meliputiuji t, uji $F$ dan koefisien determinasi.

\section{Hasil dan Pembahasan}

\section{Analisis Statistik Deskriptif}

Analisis statistik deskriptif ini digunakan untuk menunjukkan jumlah data yang digunakan dalam penelitian ini serta dapat menunjukkan nilai maksimum, nilai minimum, nilai rata-rata dan nilai standar deviasi dari masing-masing variabel. Berikut hasil olah data statistik deskiptif dapat dilihat pada tabel berikut ini :

Tabel 2. Analisis Statistik Deskriptif Descriptive Statistics

\begin{tabular}{|c|c|c|c|c|c|}
\hline & $\mathrm{N}$ & Min & Max & Mean & $\begin{array}{c}\text { Std. } \\
\text { Deviation }\end{array}$ \\
\hline $\begin{array}{l}\text { Dividend } \\
\text { Payout } \\
\text { Ratio }\end{array}$ & 45 & 6.70 & 81.71 & 27.4480 & 17.64525 \\
\hline $\begin{array}{l}\text { Return on } \\
\text { Equity }\end{array}$ & 45 & 3.61 & 23.48 & 13.9362 & 5.39503 \\
\hline $\begin{array}{l}\text { Komite } \\
\text { Audit }\end{array}$ & 45 & 2.00 & 6.00 & 3.2667 & .78044 \\
\hline $\begin{array}{l}\text { Kepemilika } \\
\text { n Asing }\end{array}$ & 45 & 2.18 & 40.85 & 16.9496 & 8.91972 \\
\hline Valid N & 45 & & & & \\
\hline
\end{tabular}

\section{Sumber: Output SPSS Versi 22.0, 2019}

Berdasarkan tabel di atas, dapat dilihat bahwa variabel Dividend Payout Ratio (Y) dengan jumlah data (N) sebanyak 45 dan memiliki nilai minimum sebesar 6.70, nilai maksimum sebesar 81.71, nilai rata-rata (mean) sebesar 27.4480 dan nilai standar deviasi sebesar 0.30225 .

Variabel Return on Equity $\left(\mathrm{X}_{1}\right)$ dengan jumlah data $(\mathrm{N})$ sebanyak 45 dan memiliki nilai minimum sebesar 3.61, nilai maksimum sebesar 23.48, nilai rata-rata (mean) sebesar 13.9362 dan nilai standar deviasi sebesar 5.39503.

Variabel Komite Audit $\left(\mathrm{X}_{2}\right)$ dengan jumlah data $(\mathrm{N})$ sebanyak 45 dan memiliki nilai minimum sebesar 2.00, nilai maksimum sebesar 6.00, nilai rata-rata (mean) sebesar 3.2667 dan nilai standar deviasi sebesar 0.78044 .

Variabel Kepemilikian Asing $\left(\mathrm{X}_{3}\right)$ dengan jumlah data $(\mathrm{N})$ sebanyak 45 dan memiliki nilai minimum sebesar 2.18, nilai maksimum sebesar 40.85, nilai rata-rata (mean) sebesar 16.9496 dan nilai standar deviasi sebesar 8.91972.

\section{Analisis Regresi Linier Berganda}

Analisis regresi linier berganda dalam penelitian ini digunakan untuk mengetahui pengaruh Return on Equity, Komite Audit dan Kepemilikan Asing terhadap Kebijakan Dividen (DPR).

Tabel 3. Analisis Regresi Linier Berganda Coefficients ${ }^{\mathrm{a}}$

\begin{tabular}{|c|c|c|c|c|c|}
\hline \multirow[t]{2}{*}{ Model } & \multicolumn{2}{|c|}{$\begin{array}{l}\text { Unstandardized } \\
\text { Coefficients }\end{array}$} & $\begin{array}{c}\text { Standard } \\
\text { ized }\end{array}$ & \multirow[t]{2}{*}{$\mathrm{t}$} & \multirow[t]{2}{*}{ Sig. } \\
\hline & B & $\begin{array}{l}\text { Std. } \\
\text { Error }\end{array}$ & Beta & & \\
\hline $\begin{array}{l}1 \\
\text { (Constant) }\end{array}$ & 37.560 & 11.661 & & 3.221 & .003 \\
\hline $\begin{array}{l}\text { Return on } \\
\text { Equity }\end{array}$ & 1.584 & .425 & .484 & 3.726 & .001 \\
\hline $\begin{array}{l}\text { Komite } \\
\text { Audit }\end{array}$ & -4.311 & 2.897 & -.191 & -1.488 & .144 \\
\hline $\begin{array}{l}\text { Kepemilik } \\
\text { an Asing }\end{array}$ & -1.068 & .261 & -.540 & -4.091 & .000 \\
\hline
\end{tabular}

a. Dependent Variable: Dividend Payout Ratio

Sumber : Output SPSS Versi 22.0, 2019

Dari tabel di atas, maka diperoleh regresi sebagai berikut:

$\mathrm{Y}=37.560+1.584 \mathrm{X}_{1}-4.311 \mathrm{X}_{2}-1.068 \mathrm{X}_{3}$

Dari persamaan regresi linier berganda tersebut dapat diinterpresentasikan sebagai berikut:

1. Nilai konstanta sebesar 37.560 artinya Return on Equity $\left(\mathrm{X}_{1}\right)$, Komite Audit $\left(\mathrm{X}_{2}\right)$ dan Kepemilikan Asing $\left(\mathrm{X}_{3}\right)$, maka potensi Kebijakan Dividen (Y) cenderung naik sebesar 37.560 .

2. Nilai koefisien regresi Return on Equity $\left(\mathrm{X}_{1}\right)$, bernilai positif sebesar 1.584 artinya jika variabel independen lain bernilai tetap dan Return on Equity $\left(\mathrm{X}_{1}\right)$, mengalami kenaikan $1 \%$, maka Kebijakan Dividen (Y) mengalami kenaikan sebesar 1.584 dan sebaliknya.

3. Nilai koefisien regresi Komite Audit $\left(\mathrm{X}_{2}\right)$, bernilai negatif sebesar 4.311 artinya jika variabel independen lain lain bernilai tetap dan Komite Audit $\left(\mathrm{X}_{2}\right)$ mengalami kenaikan $1 \%$, maka Kebijakan Dividen (Y) mengalami penurunan sebesar 4.311 dan sebaliknya.

4. Nilai koefisien regresi Kepemilikan Asing $\left(X_{3}\right)$, bernilai negatif sebesar 1.068 artinya jika variabel independen lain lain bernilai tetap dan Kepemilikan Asing $\left(\mathrm{X}_{3}\right)$ mengalami kenaikan 1\%, maka Kebijakan Dividen (Y) mengalami penurunan sebesar 1.068 dan sebaliknya.

\section{Uji Asumsi Klasik}

Uji Normalitas

Uji normalitas ini dilakukan untuk melihat apakah model regresi variabel terikat dan variabel bebas mempunyai distribusi normal atau tidaknya. 
Tabel 4. Hasil Uji Kolmogorov - Smirnov One-Sample Kolmogorov-Smirnov Test

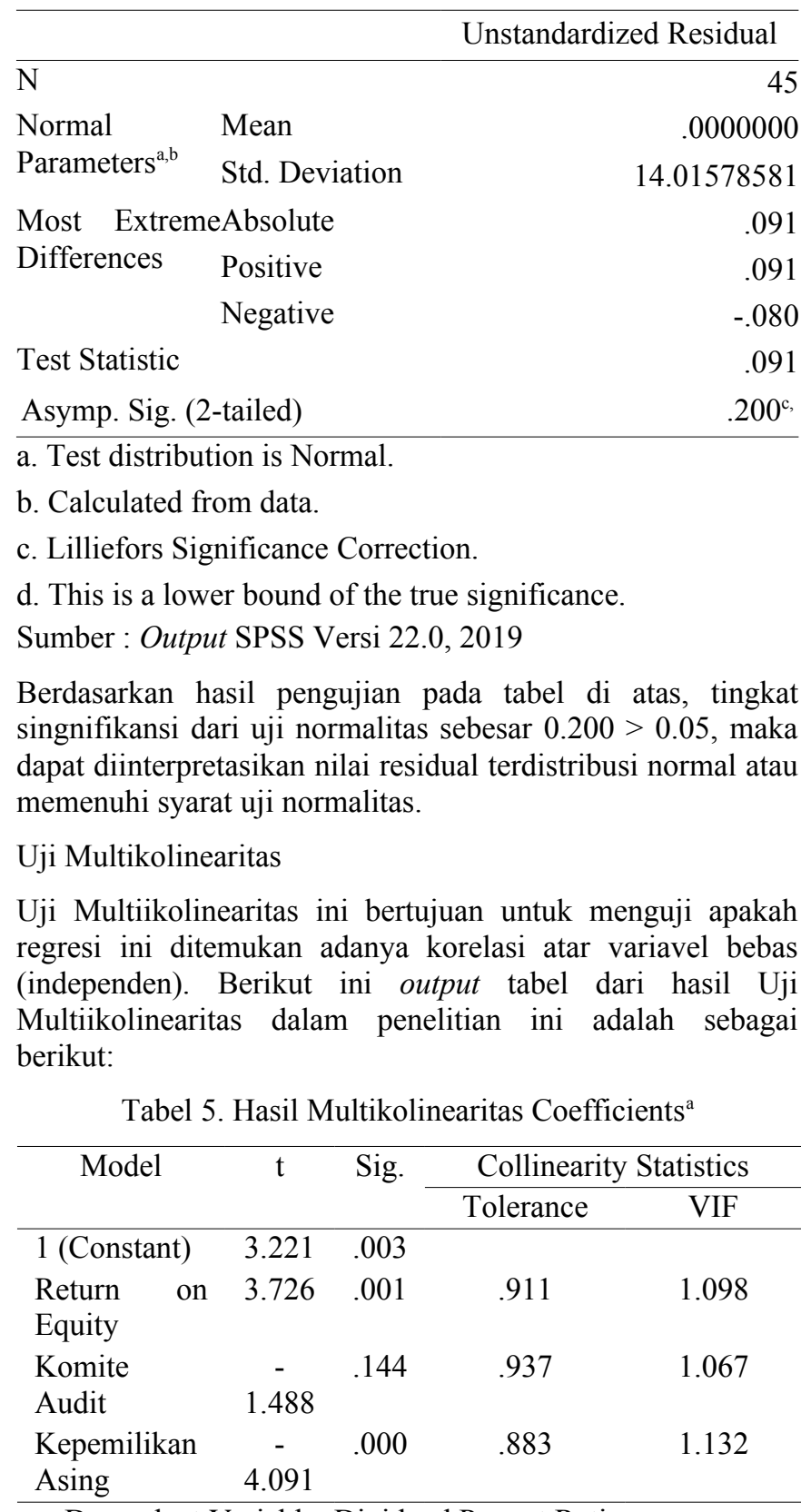

\section{a. Dependent Variable: Dividend Payout Ratio}

Sumber : Output SPSS Versi 22.0, 2019

Berdasarkan pada tabel di atas, menunjukkan bahwa hasil uji multikolinearitas menunjukkan masing-masing variabel independen (Return on Equity, Komite Audit dan Kepemilikan Asing) memiliki nilai tolerance yang lebih besar atau sama dengan 0.10 dengan nilai $\mathrm{VIF}<10$.

Maka perhitungan nilai VIF ROE sebesar $1.098<10$, Komite Audit sebesar $1.067<10$ dan Kepemilikan Asing sebesar $1.132<10$. Maka dapat diinterpretasikan bahwa pada model regresi nilai tidak multikolinearitas.

\section{Uji Heteroskedastisitas}

Uji heteroskedastisitas bertujuan untuk menguji apakah dalam suatu model regresi yang terjadi ketidaksamaan variance dari residual 1 (satu) pengamatan ke pengamatan yang lain. Jika variance dari residual 1 (satu) pengamatan ke pengamatan tetap, maka disebut Homoskedastisitas dan jika berbeda disebut heteroskedastisitas. Dalam penelitian ini untuk mengukur ada atau tidaknya heteroskedastisitas dapat dilihat pada gambar scatterplot di bawah ini:

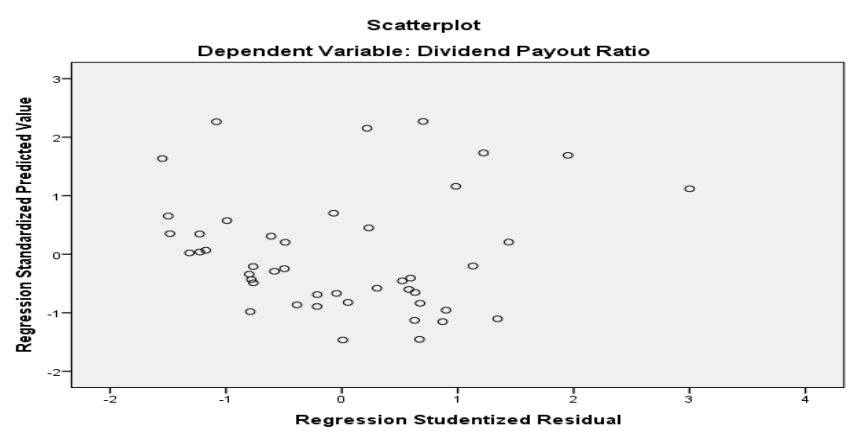

Gambar 1. Grafik Scatterplot

Sumber : Output SPSS Versi 22.0, 2019

Grafik scatterplot tersebut menunjukkan titik-titik menyebar. Dengan demikian dapat dikatakan pada model regresi terdapat kemungkinan terjadi heteroskedasitas.

Uji Autokorelasi

Uji Autokorelasi adalah keadaan di mana terjadinya korelasi antara residual pada 1 (satu) pengamatan dengan pengamatan lain pada model regresi. Uji autokorelasi digunakan untuk mengetahui ada atau tidaknya korelasi antara residual pada 1 (satu) pengamatan dengan pengamatan lain pada model regresi. Model regresi yang baik adalah yang bebas dari autokorelasi. Metode pengujian menggunakan uji DurbinWatson (uji DW).

Nilai Durbi Watson dapat dilihat melalui output tabel model summary di bawah ini:

Tabel 6. Hasil Uji Autokorelasi (Uji Durbin-Watson) Model Summary ${ }^{\mathrm{b}}$

\begin{tabular}{cccccc}
\hline Model & $\mathrm{R}$ & $\mathrm{R}$ & $\begin{array}{c}\text { Adj } \\
\text { Square }\end{array}$ & $\begin{array}{c}\text { Std. } \\
\text { Squa } \\
\text { Error of } \\
\text { tge }\end{array}$ & $\begin{array}{c}\text { Durbin- } \\
\text { Watson } \\
\text { Estimate }\end{array}$ \\
\hline 1 & $.608^{\mathrm{a}}$ & .369 & .323 & & 1.599 \\
\hline
\end{tabular}

a. Predictors: (Constant), Kepemilikan Asing, Komite Audit,

Return on Equity

b. Dependent Variable: Dividend Payout Ratio

Sumber : Output SPSS Versi 22.0, 2019

Dari tabel di atas dapat diketahui bahwa nilai Durbin Watson sebesar 1.599. Sedangkan dari tabel DW dengan signifikansi 0.05 dan jumlah data $(\mathrm{n})=45$, serta $\mathrm{k}=3(\mathrm{k}$ adalah jumlah variabel independen) diperoleh nilai dL sebesar 1.3384 dan nilai dU sebesar 1.6589. sehingga dapat dihitung 4-dU = 2.3411 dan $4-\mathrm{dL}=2.6616$.

Adapun kriteria yang ditentukan untuk memenuhi uji autokorelasi bila ada DW terletak dU $<$ DW $<4$-dU atau $(1.6589<1.599<2.3411)$. Karena hasil tersebut tidak sesuai maka peneliti melakukan uji runs test yang dapat dilihat pada tabel dibawah ini: 
Tabel 7. Hasil Uji Rans Test Runs Test

\begin{tabular}{lr}
\hline & Unstandardized Residual \\
\hline Test Value $^{\mathrm{a}}$ & -.62130 \\
Cases $<$ Test Value & 22 \\
Cases $>=$ Test Value & 23 \\
Total Cases & 4 \\
Number of Runs & 18 \\
Z & -1.50 \\
Asymp. Sig. (2-tailed) & .132 \\
\hline a. Median &
\end{tabular}

Sumber : Output SPSS Versi 22.0, 2019

Hasil uji Runs Test menunjukan bahwa nilai (Asymp.Sig. (2tailed)) sebesar 0.132. Jika nilai Asymp. Sig. (0.132) >0.05, maka dapat diinterpretasikan bahwa tidak terdapat autokorelasi dalam penelitian ini.

\section{Uji Hipotesis}

Pengujian hipotesis dalam penelitian ini digunakan untuk menguji hipotesis yang telah dirumuskan pada bab sebelumnya dan untuk mengetahui pengaruh variabel independen terhadap variabel dependen secara parsial (uji t) maupun secara simultan (uji F).

\section{Uji Statistik $\mathrm{t}$}

pada dasarnya menunjukkan seberapa jauh pengaruh satu variabel independen secara parsial dalam menerangkan variabel dependen dengan melihat tabel distribusi t maka koefisien korelasi dengan tingkat kesalahan 5\% $(0,05)$, jumlah data (n) sebanyak 45 , dan df $=n-k-1$ sehingga dapat dilihat nilai $\mathrm{df}=41$, diperoleh $\mathrm{t}_{\text {tabel }}$ sebesar 2.020 . berikut hasil uji statistik $t$ untuk pengujian secara parsial variabel independen dan variabel dependen:

Tabel 8. Hasil Uji Statistik t Coefficients ${ }^{a}$

\begin{tabular}{|c|c|c|c|c|}
\hline \multirow[t]{2}{*}{ Model } & \multirow[t]{2}{*}{$\mathrm{t}$} & \multirow[t]{2}{*}{ Sig. } & \multicolumn{2}{|c|}{ Collinearity Statistics } \\
\hline & & & Tolerance & VIF \\
\hline $\begin{array}{l}1 \\
\text { (Constant) }\end{array}$ & 3.221 & .003 & & \\
\hline $\begin{array}{l}\text { Return on } \\
\text { Equity }\end{array}$ & 3.726 & .001 & .911 & 1.098 \\
\hline $\begin{array}{l}\text { Komite } \\
\text { Audit }\end{array}$ & $\begin{array}{c}- \\
1.488\end{array}$ & .144 & .937 & 1.067 \\
\hline $\begin{array}{l}\text { Kepemilik } \\
\text { an Asing }\end{array}$ & $\begin{array}{c}- \\
4.091\end{array}$ & .000 & .883 & 1.132 \\
\hline
\end{tabular}

a. Dependent Variable: Dividend Payout Ratio

Sumber : Output SPSS Versi 22.0, 2019

Berdasarkan tabel hasil uji statistik t di atas, dapat diuraikan sebagai berikut:

1) Return on Equity $\left(\mathrm{X}_{1}\right)$

Berdasarkan hasil uji regresi $\mathrm{t}$ di atas, return on equity memiliki $t_{\text {hitung }}(3.726)>\mathrm{t}_{\text {tabel }}(2.020)$ dan nilai signifikansi 0.001 dimana nilai signifikansi $0.001<0.05$ yang berarti bahwa return on equity secara parsial berpengaruh positif dan signifikansi terhadap kebijakan dividen (DPR) dan signifikansi terhadap kebijakan dividen (DPR) dan $\mathrm{H}_{1}$ diterima.
2) Komite Audit $\left(X_{2}\right)$

Berdasarkan hasil uji regresi $\mathrm{t}$ di atas, komite audit memiliki $\mathrm{t}_{\text {hitung }}(-1.488)<\mathrm{t}_{\text {tabel }}(2.020)$ dan nilai signifikansi 0.144 dimana nilai signifikansi $0.144>$ dari 0.05 yang berarti bahwa komite audit secara parsial berpengaruh negative dan tidak signifikan terhadap kebijakan dividen (DPR) dan $\mathrm{H}_{2}$ ditolak.

3) Kepemilikan Asing $\left(X_{3}\right)$

Berdasarkan hasil regresi $\mathrm{t}$ di atas, kepemilikan asing memiliki $t_{\text {hitung }}(-4.091)<t_{\text {tabel }}(2.020)$ dan nilai signifikansi 0.000 dimana nilai signifikansi $0.000<0.05$ yang berarti bahwa kepemilikan asing secara parsial berpengaruh negatif dan signifikan terhadap kebijakan dividen (DPR) dan $\mathrm{H}_{3}$ diterima.

\section{Uji Statistik F}

Uji statistik F pada dasarnya menunjukkan apakah semua variabel independen atau bebas yang dimasukkan dalam model mempunyai pengaruh secara bersama-sama terhadap variabel dependen atau terikat. Berdasarkan tabel distribusi $\mathrm{F}$ maka koefisien korelasi dengan kesalahan 5\% (0.05), jumlah data $(\mathrm{n})$ sebanyak 45 , dan $\mathrm{df}=\mathrm{n}-\mathrm{k}-1$ sehingga didapat $\mathrm{df}=$ 41 dan $F_{\text {tabel }}$ sebesar 2.84. dari hasil pengujian simultan diperoleh hasil sebagai berikut:

Tabel 9. Hasil Uji Statistik F ANOVA ${ }^{\mathrm{a}}$

\begin{tabular}{lccccc}
\hline Model & $\begin{array}{c}\text { Sum of } \\
\text { Square }\end{array}$ & df & $\begin{array}{c}\text { Mean } \\
\text { Square }\end{array}$ & F & Sig. \\
\hline 1 & 5056.161 & 3 & 1685.387 & 7.995 & $.000^{\mathrm{b}}$ \\
$\begin{array}{l}\text { Regressi } \\
\text { on }\end{array}$ & & & & & \\
Residul & 8643.459 & 41 & 210.816 & & \\
Total & 13699.620 & 44 & & & \\
\hline
\end{tabular}

1. Dependent Variable: Dividend Payout Ratio

2. Predictors : (Constant), Kepemilikan Asing, Komite Audit, Return on Equity

Sumber : Output SPSS Versi 22.0, 2019

Berdasarkan hasil perhitungan menggunakan SPSS yang ditunjukkan oleh ANOVA $^{\mathrm{b}}$ di atas, diketahui nilai $\mathrm{F}_{\text {hitung }}$ (7.995) $>F_{\text {tabel }}(2.84)$ pada tingkat singnifikansi $F 0.000<$ 0.05 dengan demikian dapat diinterprestasikan bahwa seluruh variabel independen (return on equity, komite audit dan kepemilikan asing) secara simultan berpengaruh terhadap variabel dependen (kebijakan dividen (DPR).

\section{Analisis Koefisien Determinasi $\left(\mathbf{R}^{2}\right)$}

Analsisi koefisien determinasi $\left(\mathrm{R}^{2}\right)$ mengukur kemampuan return on equity, komite audit dan kepemilikan asing dalam menjelaskan variasi kebijakan dividen (DPR). Dalam regresi linier berganda digunakan Adjusted $R$ Square.

Tabel 6. Analisis Koefisien Determinasi Model Summary ${ }^{\mathrm{b}}$

\begin{tabular}{cccccc}
\hline Model & $\mathrm{R}$ & $\mathrm{R}$ & $\begin{array}{c}\text { Adj R } \\
\text { Square }\end{array}$ & $\begin{array}{c}\text { Std. } \\
\text { Square }\end{array}$ & $\begin{array}{c}\text { Durbin- } \\
\text { Error } \\
\text { of tge } \\
\text { Estima } \\
\text { te }\end{array}$ \\
\hline 1 & $.608^{\mathrm{a}}$ & .369 & .323 & & \multicolumn{3}{c}{1.599} \\
\hline
\end{tabular}


a. Predictors: (Constant), Kepemilikan Asing, Komite Audit,

Return on Equity

b. Dependent Variable: Dividend Payout Ratio

Sumber : Output SPSS Versi 22.0, 2019

Berdasarkan tabel 18, nilai Adjusted R Square sebesar 0.323, hal ini berarti variabel return on equity, komite audit dan kepemilikan asing menjelaskan 32.3\% variabel kebijakan dividen (DPR) sedangkan sisanya 67.7\% (100\% - 32.3\%) dijelaskan oleh variabel independen lain yang tidak diteliti.

\section{Pembahasan}

\section{Pengaruh Return on Equity terhadap Kebijakan Dividen (DPR)}

Berdasarkan tabel interpretasi di atas dapat dinyatakan bahwa variabel retun on equity berpengaruh positif dan signifikan terhadap kebijakan dividen (DPR) maka hipotesis ini diterima. Hal ini dapat dibuktikan dengan nilai signifikansi 0.01 di mana nilai signifikansi $(0.001<0.05)$ dengan nilai $\mathrm{t}_{\text {hitung }}>\mathrm{t}_{\text {tabel }}\left(\mathrm{t}_{\text {hitung }} 3.221>\mathrm{t}_{\text {tabel }} 2.020\right)$ yang berarti return on equity secara parsial berpengaruh positif dan signifikan terhadap kebijakan dividen (DPR) dan $\mathrm{H}_{1}$ diterima. Hal ini disebabkan Profitabilitas mempengaruhi kebijakan pembayaran dividen karena dividen dibagikan dari keuntungan bersih yang diperoleh dari perusahaan, maka besarnya keuntungan akan mempengaruhi besarnya dividen yang akan dibagikan. Semakin besar laba maka perusahaan cenderung akan membayarkan dividen yang tinggi kepeda pemegang saham. Penelitian ini sejalan dengan hasil penelitian yang dilakukan oleh Cholifah \& Priyadi (2014) yang menyatakan bahwa hasil profitabilitas (return on equity) berpengaruh positif terhadap kebijakan dividen.

\section{Pengaruh Komite Audit terhadap Kebijakan Dividen (DPR)}

Berdasarkan tabel interpetasi di atas dapat dinyatakan bahwa variabel komite audit berpengaruh negatif dan tidak signifikan terhadap kebijakan dividen (DPR) maka hipotesis ini diterima. Hal ini dapat dibutikan nilai signifikansi 0.144 $(0.144>0.05)$ dengan nilai $\mathrm{t}_{\text {hitung }}<\mathrm{t}_{\text {tabel }}$ (thitung $-1.488<\mathrm{t}_{\text {tabel }}$ 2.020) yang berarti komite audit secara parsial berpengaruh negatif dan tidak signifikan terhadap kebijakan dividen (DPR) dan $\mathrm{H}_{2}$ ditolak. Hal ini disebabkan besar kecilnya jumlah anggota komite audit tidak berdampak langsung terhadap jumlah pembagian dividen yang diberikan kepada pemegang saham. Penelitian ini sejalan dengan hasil penelitian yang dilakukan oleh Nimer et al. (2013) menyimpulkan bahwa tidak ada hubungan yang signifikan antara Komite Audit dengan kebijakan dividen.

\section{Pengaruh Kepemilikan Asing terhadap Kebijakan Dividen (DPR)}

Berdasarkan tabel interpetasi di atas dapat dinyatakan bahwa variabel kepemilikan asing berpengaruh negatif dan signifikan terhadap kebijakan dividen (DPR) maka hipotesis ini diterima. Hal ini dapat dibutikan dengan nilai signifikansi 0.000 dimana nilai signifikansi $(0.000>0.05)$ dengan nilai $\mathrm{t}_{\text {hitung }}<\mathrm{t}_{\text {tabel }}$ (thitung $-4.061<\mathrm{t}_{\text {tabel }} 2.020$ ) yang berarti kepemilikan asing secara parsial berpengaruh negatif dan signifikan terhadap kebijakan dividen (DPR) dan $\mathrm{H}_{3}$ diterima. Hal ini disebabkan Apabila harga saham naik, maka banyak investor asing yang tertarik untuk menanamkan modalnya pada perusahaan. Biasanya pihak asing cenderung lebih menyukai perusahaan menahan labanya dari pada membayarkan dividen hal ini karena pajak atas dividen yang tinggi terutama bagi investor asing. Semakin banyak kepemilikan asing di perusahaan maka perusahaan cenderung akan meningkatkan keuntungan perusahaan sehingga dapat membayarkan dividen yang tinggi kepeda pemegang saham. Penelitian ini sejalan dengan hasil penelitian yang dilakukan oleh Chai (2010) kepemilikan asing memiliki pengaruh positif terhadap kebijakan dividen.

\section{Pengaruh Return on Equity, Komite Audit dan} Kepemilikan Asing terhadap Kebijakan Dividen (DPR)

Berdasarkan tabel interpretasi di atas dapat dinyatakan bahwa variabel return on equity, komite audit dan kepemilikan asing berpengaruh positif dan signifikan terhadap kebijakan dividen (DPR) maka hipotesis ini diterima. Hal ini dapat dibuktikan dengan nilai signifikansi 0.000 di mana nilai signifikansi $(0.000<0.05)$ dengan nilai $\mathrm{t}_{\text {hitung }}>\mathrm{t}_{\text {tabel }}\left(\mathrm{t}_{\text {hitung }}\right.$ $7.995>\mathrm{t}_{\text {tabel }} 2.84$ ) yang berarti return on equity, komite audit dan kepemilikan asing secara parsial berpengaruh positif dan signifikan terhadap kebijakan dividen (DPR) dan $\mathrm{H}_{4}$ diterima. Berdasarkan pada tabel 20 menunjukkan bahwa nilai Adjusted $R$ Square sebesar 0.323, hal ini berarti variabel return on equity, komite audit dan kepemilikan asing menjelaskan $32.3 \%$ variabel kebijakan dividen (DPR) sedangkan sisanya $67.7 \%(100 \%-32.3 \%)$ dijelaskan oleh variabel lain yang tidak diteliti.

\section{Simpulan}

\section{Kesimpulan}

Berdasarkan hasil analisis yang telah dilakukan pada penelitian ini, maka dapat ditarik simpulan bahwa Retrurn on Equity dan Kepemilikan Asing terhadap Dividend Payout Ratio yang berpengaruh signifikan sedangkan Komite Audit tidak berpengaruh signifikan terhadap Dividend Payout Ratio.

\section{Keterbatasan}

Penelitian ini memiliki beberapa keterbatasan diantaranya yaitu peneliti hanya meneliti Return on Equity, Komite Audit dan Kepemilikan. Periode penelitian hanya 5 tahun yang diteliti. Objek penelitian hanya pada subsektor Properti, Real Estate, Konstruksi dan Bangunan. Sehingga peneliti menyarankan kepada peneliti selanjutnya untuk menambah variabel, periode penelitian dan objek penelitian untuk di perluas agar bisa lebih baik dari penelitian ini.

\section{Referensi}

Chai, D. H. (2010). Foreign Corporate Ownership and Dividends. In $C B R$ Research Programme on Corporate Governance. (Issue 401).

Cholifah, N., \& Priyadi, M. P. (2014). Analisis Pengaruh Kebijakan Pendanaan, Kepemilikan Manajerial, Profitabilitas Dan Growth Terhadap Kebijakan Dividen Pada Perusahaan Manufaktur Di Bursa Efek Indonesia.

Jakarta \& Indonesia Stock Exchange | Indonesia Finance Market. (n.d.). Retrieved March 14, 2020, from https://www.idnfinancials.com/

Kumalasari, A. (2017). Pengaruh Good Corporate Governance dan Kebijakan Dividen terhadap Nilai Perusahaan. E-Journal Sekolah Tinggi Ilmu Ekonomi Indonesia (STIESIA), 6(6), 1-20.

Linawati, \& Amilin. (2015). Cash Ratio, Debt to Equity Ratio, Return on Assets, Firm Size, Growth and Dividend Payout Ratio pada Perusahaan Manufaktur di Indonesia. Jurnal Riset Akutansi Dan 
Perpajakan, 2(1), $55-64$. jrap.univpancasila.ac.id/index.php/JRAP/article/download/32/19

Lucyanda, J., \& Lilyana. (2012). Pengaruh Free Cash Flow dan Struktur Kepemilikan terhadap Dividend Payout Ratio. Jurnal Dinamika Akuntansi, 4(2), 129-138.

Nanang, M. (2014). Metode Penelitian Kuantitatif: Analisis Isi dan Analisis Data Sekunder. Depok: PT RajaGrafindo Persada.

Nimer, M. Al, Omari, R. Al, \& Warrad, L. (2013). The Impact of Liquidity on Jordanian Banks Profitability through Return on Assets. Interdisciplinary Journal of Contemporary Research in Business, 5, 70-76.

PT Bursa Efek Indonesia. (n.d.). Retrieved March 14, 2020, from https://www.idx.co.id/
Septiani, V. (2013). Pengaruh Mekanisme Corporate Governance Leverage Profitabilitas dan Kebijakan Dividen Terhadap Manajemen Laba. Universitas Muhammadiyah Yogyakarta.

Setyaningrum, A. N. (2016). Pengaruh ESOP terhadap Kualitas Implementasi Corporate Governance dan Kinerja Perusahaan. Jurnal Ilmiah Mahasiswa FEB, 1(1), 1-26.

Sudana, I. M. (2011). Manajemen Keuangan Perusahaan Teori dan Praktek. Jakarta: Erlangga.

Sugiyono. (2011). Metode Penelitian: Kuantitatif, Kualitatif, dan R\&D. Alfabeta.

Wahyudi, A. (2013). Pengaruh Good Corporate Governance, Rasio Keuangandan Cash Position Terhadap Kebijakan Dividen pada Perusahaan Manufaktur di Bursa Efek Indonesia. Journal Sekolah Ilmu Ekonomi (STIESIA), 2(2), 1-16. 